\title{
KAJIAN KINERJA BADAN LINGKUNGAN HIDUP (BLH) DALAM RANGKA IMPLEMENTASI RKL-RPL OLEH PEMRAKARSA, KASUS : KABUPATEN KOTAWARINGIN BARAT, KALIMANTAN TENGAH
}

\author{
Andri Saputra', Su Ritohardoyo, Agus Joko Pitoyo, Sigit Heru Murti B.S., dan Luthfi Muta'ali ${ }^{2,3,4}$
}

BLH Kabupaten Waringin Barat Pangkalan Bun, Kal-Teng, Indonesial, Fakutlas Geografi, Universitas Gadjah Mada, Yogyakarta, Indonesia ${ }^{2,3,4,}$

andriboen@gmail.com

Diterima : Desember 2015. ; Direvisi : Juni 2016.; Dipubikasikan: September 2016

\begin{abstract}
ABSTRAK Pemrakarsa suatu usaha/kegiatan wajib mempunyai ijin lingkungan yang dikeluarkan oleh Badan Lingkungan Hidup (BLH) dalam bentuk RKL-RPL. Melalui RKL dan RPL, dampak lingkungan akibat suatu kegiatan akan mampu mencegah, mengendalikan, dan menanggulangi sehingga dapat meminimalkan dampak negatif dan memaksimalkan dampak positif dari suatu rencana kegiatan. Penelitian ini bertujuan untuk mengetahui kinerja monitoring dan evaluasi terhadap BLH, menemukan persepsi publik terhadap kinerja monev, menganalisa faktor-faktor yang berpengaruh, dan merumuskan strategi kebijakan untuk meningkatkan kinerja monev. Penelitian ini menggunakan metode pendekatan kualitatif yang menekankan pada analisis terhadap masalah tertentu secara mendalam dan eksploratif seputar kinerja monev BLH Kobar dalam implementasi RKL-RPL. Hasil penelitian menunjukkan bahwa monev RKL-RPL belum berjalan secara optimal sehingga perlu adanya pembenahan pada pelaksanaan dan komitmen pemerintah daerah, lembaga publik, dan partisipasi publik dalam prosesnya. Strategi untuk meningkatkan kinerja monev RKL-RPL terdapat delapan langkah yaitu (1) revisi program prioritas pemerintah daerah, (2) penyusunan perda pendukung monev, (3) pengembangan program publikasi monev, (4) memfasilitasi pembentukan forum diskusi dan komunitas sosial peduli lingkungan, (5) perbaikan manajemen SDM, (6) peningkatan kapasitas pemrakarsa secara berkala, (7) peningkatan sarana dan prasarana pendukung monev, dan (8) revisi teknis pelaksanaan monev RKL-RPL.
\end{abstract}

Kata kunci: Badan Lingkungan Hidup; kinerja monitoring dan evaluasi; Kotawaringin Barat.

ABSTRACT The initiator of a business/activity must have an environmental permits by the Environment Agency (BLH) in the form of RKL-RPL. Through RKL and RPL, the environmental impact of activities will be able to prevent, control, and mitigate, so as to minimize negative impacts and maximize the positive impact of an activity plan. This study aims to determine the performance monitoring and evaluation of BLH, find the public's perception of the performance monitoring and evaluation, analyze the factors that influence, and formulate strategies to improve performance monitoring and evaluation policies. This study uses qualitative approach method that emphasizes on the analysis of specific issues in depth and exploratory about BLH Kobar monitoring and evaluation performance in the implementation of the RKL-RPL. The results show that the monitoring and evaluating of RKL-RPL has not run optimally so that the need for improvement in the implementation and commitment of local government, public institutions, and public participation in the process. Strategies to improve performance monitoring and evaluation of RKL-RPL there are eight steps: (1) the revision of the priority programs of the local government, (2) local regulations may support monitoring and evaluation, (3) development program publications monitoring and evaluation, (4) facilitate the establishment of a discussion forum and social community care for the environment, (5) improvement of human resource management, (6) an increase in the capacity of the proponent periodically, (7) the improvement of facilities and infrastructure to support monitoring and evaluation, and (8) the revision of the technical implementation of monitoring and evaluation of RKL-RPL.

Key words: environmental agency; performance monitoring and evaluation; West Kotawaringin.

\section{PENDAHULUAN}

Izin lingkungan merupakan salah satu perizinan dasar yang wajib dimiliki oleh suatu usaha/kegiatan yang wajib AMDAL atau UKL-UPL dalam rangka perlindungan dan pengelolaan lingkungan hidup. Izin lingkungan diberikan kepada pemrakarsa setelah melalui uji kelayakan dokumen AMDAL yang dilakukan oleh komisi penilai AMDAL daerah. Bagi pemrakarsa yang sudah mendapatkan izin lingkungan berkewajiban untuk menjalankan dan melaporkan realisasi rencana pengelolaan lingkungan dan rencana pemantauan lingkungan pengelolaan lingkungan (RKL-RPL) ke BLH setiap semester. Selanjutnya, BLH melalui Pejabat Pengawas Lingkungan Hidup (PPLH) bertugas melakukan monitoring dan evaluasi (monev) terhadap implementasi RKL-RPL untuk memastikan apakah pemrakarsa telah menjalankan kewajiban lingkungan dengan baik atau sebaliknya. Ketika pemrakarsa lalai dalam menjalankan kewajiban RKLRPL, maka berpotensi menimbulkan pencemaran lingkungan dan patut mendapat sanksi sesuai ketentuan yang diatur dalam UU Nomor 32 Tahun 
2009. Dengan demikian, fungsi monev RKL-RPL yang dijalankan BLH sangat penting dalam mengontrol dan meningkatkan ketaatan pemrakarsa terhadap kewajiban lingkungan.

Dalam kenyataannya, capaian kinerja monev RKLRPL masih rendah karena masih banyak pemrakarsa yang tidak mematuhi kewajiban pelaksanaan dan pelaporan RKL-RPL. Meski demikian, beragam masalah yang menyertai kinerja monev RKL-RPL belum terindentifikasi dan terakomodasi dalam evaluasi kinerja pemerintah. Sebagai contoh, evaluasi kinerja tahunan dalam bentuk Laporan Akuntabilitas Kinerja Pemerintah Daerah (LAKIP) yang hanya memuat capaian indikator fisik dan keuangan belaka. Oleh karena itu, dipandang perlu untuk melakukan kajian kinerja monev BLH dengan menggunakan indikator-indikator eksternal (di luar pemerintah) dengan melibatkan persepsi atau peniaian publik.. Hal ini dapat ditempuh dengan menggunakan pendekatan kualilatif sehingga akan diperoleh gambaran kinerja monev yang objektif beserta masalah yang dihadapi.

Berdasarkan perumusan masalah diatas, maka tujuan penelitian ini adalah sebagai berikut: (1) mengetahui kinerja monev BLH Kobar dalam implementasi RKL-RPL; (2) menemukan konsep persepsi publik terhadap kinerja monev RKL-RPL ; (3) menganalisa faktor faktor yang mempengaruhi kinerja monev RKL-RPL ; serta (4) merumuskan strategi kebijakan untuk meningkatkan kinerja monev RKLRPL

\section{Pengertian Organisasi}

Organisasi berasal dari kata organism yang berarti menciptakan struktur dengan bagian bagian yang diintegrasikan sedemikian rupa, sehingga hubungannya satu sama lain terikat oleh hubungan secara keseluruhan (Hasibuan, 1996). Menurut Kamus Besar Bahasa Indonesia (KBBI), organisasi adalah kesatuan susunan yang terdiri atas bagian-bagian orang dalam perkumpulan untuk tujuan tertentu. Definisi lain yakni kelompok kerja sama antara orang orang yang diadakan untuk mencapai tujuan bersama. Menurut Etziomi (1976), organisasi unit sosial adalah wilayah organisasi (atau pengelompokkan manusia) yang sengaja dibangun dan direkonstruksi untuk mencapai tujuan tertentu.

Shafrizt dan Russel (1997) dalam Keban (2008) mendefinisikan organisasi sebagai suatu kelompok orang yang bekerja sama untuk mencapai tujuan tertentu. Dalam pengertian ini, organisasi merupakan kumpulan orang orang yang dikelompokkan dalam suatu hubungan kerjasama untuk mencapai tujuan bersama. Pengelompokkan orang orang tersebut didasarkan kepada prinsip prinsip pembagian kerja, peranan dan fungsi, hubungan, prosedur, aturan standar kerja, tanggung jawab dan otoritas tertentu. Adapun organisasi yang dimaksud dalam penelitian kali ini adalah Badan Lingkungan Hidup (BLH) Kabupaten Kotawaringin Barat (Kobar) sebagai instansi yang bertanggung jawab dalam perlindungan dan pengelolaan lingkungan hidup di daerah. BLH Kobar memiliki struktur, pembagian tugas dan aparatur yang saling bekerjasama dalam menjalankan program-program lingkungan hidup.

\section{Pengukuran Kinerja Organisasi}

Konsep kinerja pada dasarnya dapat dilihat dari dua segi, yaitu kinerja pegawai (per individu) dan kinerja organisasi. Kinerja pegawai adalah hasil kerja perseorangan dalam suatu organisasi. Sedangkan kinerja organisasi adalah totalitas hasil kerja yang dicapai suatu organisasi. Kinerja pegawai dan kinerja organisasi memiliki keterkaitan yang sangat erat. Tercapainya tujuan organisasi tidak bisa dilepaskan dari sumber daya yang dimiliki organisasi yang dimiliki atau dijalankan pegawai yang berperan aktif sebagai pelaku dalam upaya mencapai tujuan organisasi (Pasolong, 2008).

Istilah kinerja merupakan terjemahan dari performance yang sering diartikan oleh para cendikiawan sebagai "penampilan", "unjuk kerja" atau prestasi. Dalam kamus Illustrated Oxford Dictionary (1998:606), istilah ini menunjukkan the execution or fulfilment of duty (pelaksanaan atau pencapaian dari suatu tugas) (Keban, 2008). Adapun Rue \& Byars (1981:375) dalam Pasolong (2008) mendefinisikan kinerja sebagai tingkat pencapaian hasil (degree of accomplihsment). Kinerja organisasi yang dimaksud dalam penelitian kali ini adalah kinerja monitoring dan evaluasi (monev) BLH dalam implementasi RKL-RPL di Kabupaten Kobar.

Pengukuran kinerja merupakan kunci penting menuju perbaikan dan kemajuan baik bagi individu maupun bagi suatu lembaga. Hanya dengan pengukuran tersebut dapat dilihat apakah seseorang dan suatu lembaga telah berhasil atau sebaliknya gagal dalam mengemban misi lembaganya dan menjalankan tugas, pokok, dan fungsinya. Bila kita tidak menilai kinerja, maka kita tidak dapat menemukan apakah suatu organisasi atau individu sedang berada pada arah yang benar atau tidak, atau telah mencapai apa yang diinginkan atau tidak (Keban, 2008).

Menurut Dwiyanto (2006), pengukuran kinerja birokrasi publik tidak cukup hanya dilakukan dengan 
menggunakan indikator-indikator yang melekat para birokrasi itu, seperti efisiensi dan efektivitas. Namun, harus dilihat juga dari indikator indikator yang melekat pada pengguna jasa seperti kepuasan pengguna jasa, akuntabilitas, dan responsivitas. Tujuan utama pembentukan birokrasi adalah untuk melayani kepentingan publik. Sehingga, menjadi sebuah kewajiban bagi birokrasi untuk mempertanggung jawabkan kinerja atau program yang dijalankan kepada publik sebagai pihak yang dilayani. Berhasil tidaknya sebuah program atau kebijakan tidak lagi bergantung pada klaim sepihak birokrasi selaku penyelenggara dengan hanya bersandar pada indikator internal organisasi semata. Namun, harus didukung oleh pengakuan dan partisipasi publik sebagai objek yang merasakan langsung dampak kebijakan tersebut. Lenvine (1990) dan Darwin (1997) dalam Widodo (2001) mengusulkan tiga konsep yang bisa dipergunakan untuk mengukur kinerja organisasi publik yaitu : akuntabilitas (accountability), responsibilitas (responsibility), dan responsivitas (responsiveness). Penelitian ini akan mengukur kinerja BLH khusus dalam monev RKL-RPL. Karena penelitian ini bersifat kualitatif, indikator yang digunakan berasal dari persepsi para responden. Sedangkan penggunaan teori-teori di atas hanya sebagai alat bantu bagi peneliti untuk memahami objek penelitian.

\section{Persepsi}

Menurut Darsono (2006), persepsi adalah penyimpulan dan penafsiran objek atau peristiwa. Untuk dapat menyimpulkan dan menafsirkan objek harus didahului oleh sensasi. Sensasi adalah kemampuan indra menangkap objek atau persitiwa kemudian melahirkan pengalaman dan pengetahuan. Lebih lanjut Darsono menjelaskan bahwa persepsi manusia terhadap objek atau peristiwa ditentukan oleh beberapa unsur antara lain (1) ideologi yaitu keyakinan berdasar ilmu pengetahuan (2) kebiasaan (pola perilaku) yaitu pola perilaku efektif untuk mencapai tujuan (3) kesiapan mental yaitu kesiapan mental terhadap apa yang ingin dipersepsi (4) motivasi yaitu kekuatan pendorong untuk memerhatikan objek (5) keragaman stimuli yaitu makin beragam makin kurang tajam persepsinya dan (6) situasi yaitu kondisi yang dapat mengubah perhatian. Definisi ini semakin diperkuat oleh pendapat Thoha (2007) yang menyatakan bahwa persepsi hakikatnya adalah proses kognitif yang dialami oleh setiap orang di dalam memahami informasi tentang lingkungannya baik lewat penglihatan, pendengaran, penghayatan, perasaan dan penciuman. Kunci untuk memahami persepsi adalah terletak pada pengenalan bahwa persepsi itu merupakan suatu penafsiran yang unik terhadap situasi dan bukannya suatu pencatatan yang benar terhadap situasi.

Batasan persepsi dalam penelitian ini adalah penafsiran dan penilaian subjektif stakeholder terhadap kinerja BLH dalam monev RKL-RPL. Subjektif menunjukkan sifat penilaian yang berdasarkan kapasitas, pengalaman dan tingkat pengetahuan yang berbeda antara satu stakeholder dengan yang lain. Stakeholder yang dimaksud adalah para responden yang terlibat dalam proses monev RKL-RPL meliputi pemrakarsa sebagai pelaksana RKL-RPL, BLH sebagai institusi pelaksana, masyarakat umum sebagai objek terkena dampak kebijakan dan LSM beseta DPRD sebagai kekuatan kontrol pemerintah. Perspesi stakeholder merupakan komponen penting sebagai sumber data primer dalam menggambarkan capaian kinerja monev RKL-RPL, mengungkap faktor-faktor yang mempengaruhi kinerja monev RKL-RPL, dan sebagai bahan dalam merumuskan strategi peningkatan kinerja monev.

\section{Faktor-faktor Yang Mempengaruhi Kinerja Organisasi}

Tinggi rendahnya kinerja sebuah organisasi ditentukan oleh sejumlah faktor yang saling berhubungan antara satu dengan yang lain. Menurut Pasolong (2008), faktor faktor yang mempengaruhi kinerja organisasi terdiri atas kemampuan, kemauan, energi, teknologi, kompensasi, kejelasan tujuan dan keamanan. Salusu (1996) mengungkapkan bahwa terdapat dua faktor stratejik yang dapat mempengaruhi kinerja organisasi yakni kekuatan dan kelemahan. Kekuatan adalah situasi dan kemampuan internal yang bersifat positif, yang memungkinkan organisasi memiliki keuntungan stratejik dalam mencapai sasarannya. Sedangkan kelemahan adalah situasi dan ketidakmampuan internal yang mengakibatkan organisasi tidak dapat mencapai sasarannya (Higgins, 1985). Faktor faktor yang perlu di perhitungkan dalam melihat kemampuan internal organisasi antara lain struktur organisasi, sumber daya baik dana mupun tenaga, lokasi, fasilitas yang dimiliki, integritas seluruh karyawan dan integritas kepemimpinan. Adapun lingkungan eskternal terdiri atas dua faktor stratejik yaitu peluang dan ancaman atau tantangan.

Higgins (1985) mengartikan peluang sebagai situasi dan faktor faktor eksternal yang membantu organisasi mencapai atau bahkan bisa melampaui sasarannya. Sedangkan ancaman adalah faktor faktor eksternal 
yang menyebabkan organisasi tidak dapat mencapai sasarannya. Dalam mengamati lingkungan eksternal itu, ada beberapa sektor yang peka secara stratejik artinya bisa menciptakan peluang atau sebaliknya merupakan ancaman. Perkembangan teknologi misalnya, peraturan perundang-undangan, atau situasi keuangan dapat saja memberi keuntungan atau kerugian bagi organisasi. Tetapi yang jelas, kata William Cohen (David, 1989) ialah bahwa peluang dan ancaman hadir pada setiap saat dan senantiasa melampaui sumber daya yang tersedia. Adapun Goggin (1990) berpendapat bahwa kapasitas organisasi dapat memberi keberhasilan implementasi sebuah program atau kegiatan. Kapasitas organisasi dipengaruhi oleh tiga hal yakni struktur organisasi, personel/sumber daya manusia (SDM) dan finansial (keuangan). Sementara itu, faktor-faktor yang mempengaruhi kinerja monev BLH tidak selalu ditentukan oleh teoriteori yang ada karena tergantung dari persepsi dan pengalaman informan yang terlibat dalam monev RKLRPL.

\section{Monitoring dan Evaluasi (Monev)}

Menurut Suryana (2010), monitoring dan evaluasi adalah dua kata yang memiliki aspek kegiatan yang berbeda yaitu kata monitoring dan evaluasi. Monitoring merupakan kegiatan untuk mengetahui apakah program yang dibuat itu berjalan dengan baik sebagaiman mestinya sesuai dengan yang direncanakan, adakah hambatan yang terjadi dan bagaiman para pelaksana program itu mengatasi hambatan tersebut. Monitoring ditujukan untuk memperoleh fakta, data dan informasi tentang pelaksanaan program, apakah proses pelaksanaan kegiatan dilakukan seusai dengan apa yang telah direncankan. Proses dasar dalam monitoring ini meliputi tiga tahap yaitu: (1) menetapkan standar pelaksanaan; (2) pengukuran pelaksanaan; (3) menentukan kesenjangan (deviasi) antara pelaksanaan dengan standar dan rencana. Selanjutnya temuantemuan hasil monitoring adalah informasi untuk proses evaluasi sehingga hasilnya apakah program yang ditetapkan dan dilaksanakan memperoleh hasil yang berkesuaian atau tidak.

Penilaian (evaluasi) merupakan tahapan yang berkaitan erat dengan kegiatan monitoring, karena kegiatan evaluasi dapat menggunakan data yang disediakan melalui kegiatan monitoring. Evaluasi bertujuan untuk mengetahui apakah program itu mencapai sasaran yang diharapkan atau tidak, evaluasi lebih menekankan pada aspek hasil yang dicapai (output). Evaluasi baru bisa dilakukan jika program itu telah berjalan dalam suatu periode, sesuai dengan tahapan rancangan dan jenis program yang dibuat dan dilaksanakan. Adapun yang dikaji dalam penelitian ini adalah optimal tidaknya fungsi monev implementasi RKL-RPL. Dalam konteks ini, RKL-RPL merupakan tolok ukur atau standar untuk melakukan monev. Kegiatan monitoring oleh BLH dilakukan dalam bentuk pemantauan terhadap realisasi kegiatan RKLRPL oleh pemrakrasa. Sedangkan evaluasi merupakan penilaian akhir apakah kegiatan yang dilaksanakan sudah memenuhi atau sesuai ketentuan RKL-RPL.

Dokumen AMDAL memiliki peran strategis sebagai instrumen perizinan dan pencegahan pencemaran lingkungan yang bersifat wajib (memaksa). Ketika dokumen AMDAL telah dinyatakan layak lingkungan, maka langkah selanjutnya adalah memastikan pemrakarsa menjalankan seluruh kewajiban lingkungan yang tertuang dalam dokumen RKL-RKL melalui kegiatan monev oleh BLH. Optimal tidaknya tugas- tugas monev yang dilakukan BLH akan turut menentukan tingkat ketaatan pemkarsa dalam menjalankan kewajiban RKL-RPL. Kelalaian pemkarsa dalam menjalankan kewajiban RKL-RPL berpotensi besar menimbulkan pencemaran dan degradasi lingkungan. Sebaliknya, ketika pemkarsa taat dalam menjalankan kewajiban RKL-RPL, maka akan menjamin kelestarian dan keberlanjutan fungsi lingkungan hidup.

Sebagai langkah awal dalam upaya mewujudkan fungsi monev BLH yang optimal adalah dengan melakukan pengukuran kinerja monev BLH agar dapat diketahui sejauh mana capaian yang telah berhasil diraih. Capaian kinerja BLH tidak diukur menggunakan indikator-indikator baku versi pemerintah sebagaimana yang lazim dilakukan selama ini. Namun, mengacu pada persepsi, penilaian dan tanggapan dari informan terpilih agar diperoleh suatu hasil pengukuran yang objektif dan sejalan dengan aspirasi publik. Sejauh mana capaian kinerja monev BLH dalam monev RKL-RPL sangat pengaruhi oleh banyak faktor baik yang bersifat internal maupun eksternal. Hasil kajian mengenai capaian dan faktofaktor yang menghambat kinerja BLH kemudian menjadi landasan dalam merumuskan strategi untuk meningkatkan kinerja monev RKL-RPL. Peningkatan kinerja monev BLH diharapkan akan mampu meningkatkan ketaatan pemrakarsa dalam menjalankan kewajiban RKL-RPL sehingga kelestarian lingkungan tetap terjaga. 


\section{METODE PENELITIAN}

Dalam penelitian kali ini menggunakan pendekatan kualitatif. Menurut Moleong (2006), penelitian kualitatif adalah penelitian yang bermaksud untuk memahami fenomena tentang apa yang dialami oleh subjek penelitian misalnya perilaku, persepsi, motivasi, tindakan dan lain lain secara holistik dan dengan cara deskripsi dalam bentuk kata kata dan bahasa, pada suatu konteks khusus yang alamiah dengan dengan memanfaatkan berbagai metode alamiah. Azwar (1998) menambahkan bahwa penelitian kualitatif lebih menekankan analisis terhadap dinamika hubungan antarfenomena yang diamati dengan menggunakan logika ilmiah. Desain penelitian yang dipilih adalah deksriptif kualitatif dengan memusatkan diri pada bidang masalah tertentu secara mendalam dan eksploratif. Bidang yang menjadi fokus adalah seputar kinerja monev BLH Kobar dalam implementasi RKLRPL.

Adapun unit analisis dalam penelitian ini adalah sejumlah individu dari berbagai kelompok yang terlibat dalam proses monev BLH Kobar terhadap implementasi RKL-RPL dengan menggunakan teknik purposive sampling. Ada lima kelompok informan yang dianggap representatif meliputi aparatur BLH sebagai pengawas, pihak pemrakarsa sebagai pelaksana wajib RKL-RPL, masyarakat sebagai objek terkena dampak, anggota DPRD Kabupaten Kobar dan LSM lingkungan sebagai kelompok kontrol sekaligus mitra masyarakat serta pemerintah.

Dalam penelitian kualitatif, peneliti menggunakan teknik pengumpulan data berupa wawancara mendalam, studi pustaka/dokumen, dokumentasi dan gabungan (triangulasi sumber). Sedangkan teknik analisis data mengacu pada metode perbandingan tetap atau constant comparative method yang dilakukan melalui empat tahap yaitu reduksi data, kategorisasi, sintesisasi dan menjawab pertanyaan penelitian. Penelitian ini menggunakan teorisasi data model induksi yakni membangun teori dari hasil analisa data dilapangan. Sementara itu, uji keabsahan data menggunakan triangulasi sumber yakni dengan cara mengecek data yang telah diperoleh melalui beberapa sumber.

Kabupaten Kotawaringin Barat (Kobar) dengan ibukota Pangkalan Bun adalah satu dari 14 kabupaten/kota yang ada di wilayah Provinsi Kalimantan Tengah. Luas wilayah Kabupaten Kobar tercatat seluas $10.759 \mathrm{~km}^{2}$. Secara geografis, Kabupaten Kobar terletak diantara $1^{0} 19^{\prime}$ sampai dengan $3^{0} 36^{\prime}$
Lintang Selatan dan $110^{\circ} 25^{\prime}$ sampai dengan $112^{\circ} 50^{\prime}$ Barat Timur, dengan batas wilayah sebagai berikut :

- Sebelah Utara dengan Kabupaten Lamandau

- Sebelah Selatan dengan Laut Jawa

- Sebelah Timur dengan Kabupaten Seruyan

- Sebelah Barat dengan Kabupaten Sukamara dan Kabupaten Lamandau

Topografis Kabupaten Kobar digolongkan menjadi empat bagian dengan ketinggian antara $0-500$ meter dari permukaan laut dan kemiringan antara $0-40$ persen yaitu dataran, daerah dataran berombak, daerah berombak berbukit, dan daerah berbukit-bukit. Terdapat 3 (tiga) sungai besar yang melintasi Kabupaten Kobar yaitu Sungai Arut, Sungai Kumai dan Sungai Lamandau dengan kedalaman rata-rata 5 meter dan lebar 100 sampai 300 meter. Selain itu, masih terdapat pula ratusan anak sungai /cabang yang alirannya bermuara ke sungai-sungai besar. Sungai Arut dan Sungai Lamandau memiliki lebih dari 130 anak sungai. Sedangkan Sungai Kumai memiliki sekitar 30 anak sungai.

Kabupaten Kotawaringin Barat terletak pada daerah beriklim panas dan lembab. Hal ini disebabkan secara geografis Kabupaten Kobar masih berada di sekitar garis khatulistiwa dan bercurah hujan tinggi. Suhu maksimum berkisar $30,9{ }^{\circ} \mathrm{C}-32,7{ }^{\circ} \mathrm{C}$ dan suhu minimum antara $22,5^{\circ} \mathrm{C}-23,7^{\circ} \mathrm{C}$. Rata-rata kecepatan angin dalam 10 tahun terakhir berkisar antara $4-6$ knot. Kecepatan angin tertinggi terjadi pada bulan Agustus dan September. Jenis tanah yang terdapat di Kabupaten Kotawaringin Barat terdiri atas enam macam yakni podsolik merah kuning, kompleks podsolik (podsolik merah kuning-podsol), kompleks regosol, alluvial, orgonosol, dan oksisol (lateritik). Jenis tanah yang paling banyak adalah podsolik merah kuning. Perbedaan jenis tanah mempengaruhi pola pemanfaatan lahan dan aktivitas ekonomi yang dilakukan masyarakat. Untuk pemanfaatan lahan, secara umum terbagi menjadi tiga kelompok yakni pemanfaatan tanah menetap, pemanfaatan tanah tidak menetap dan tanah yang belum diusahakan. Kategori pertama yakni pemanfaatan tanah menetap terdiri atas pemukiman, perkebunan, persawahan, dan kebun campuran. Untuk pemanfaatan tanah tidak menetap meliputi perladangan, semak dan alang-alang serta hutan belukar. Dan kategori tanah yang belum diusahakan adalah kawasan hutan, sungai dan danau.

Adapun pola sebaran aktivitas ekonomi sangat beragam dan tergantung pada sumber daya yang terkandung pada masing-masing kawasan. Pada kawasan pesisir yang terdapat di Kecamatan Kumai 
menjadi sentra pengembangan tanaman kelapa. Di wilayah selatan meliputi Kecamatan Arut Selatan, Kumai dan Kotawaringin Lama berpotensi menjadi kawasan pengembangan tanaman padi. Sedangkan untuk wilayah Kecamatan Pangkalan Lada, Pangkalan Banteng, Kecamatan Arut Utara bagian hulu mayoritas dimanfaatkan sebagai kawasan perkebunan berupa komoditas karet dan kelapa sawit. Bahkan, pola pengembangan perkebunan yang tidak terkendali menyebabkan sebagian wilayah Kecamatan Arut Selatan dan Kumai beralih fungsi menjadi perkebunan kelapa sawit skala besar. Sementara itu, untuk potensi pertambangan terpusat pada dua wilayah yakni Kecamatan Kumai yang dimanfaatkan sebagai lokasi pertambangan pasir zirkon dan Kecamatan Arut Utara bagian hulu yang dikelola menjadi area pertambangan emas dan hutan tanaman industri (HTI).

\section{HASIL DAN PEMBAHASAN}

\section{Kinerja Monev BLH Kobar}

Berdasarkan penilaian dari para informan, secara umum kinerja BLH dalam monev RKL-RPL sudah berjalan namun belum optimal karena masih mengandung sejumlah kelemahan. Kinerja monev RKL-RPL dinilai sudah berjalan berdasarkan atas tiga indikator yakni (1) pengakuan dari para informan, (2) dokumen administrasi berupa laporan RKL-RPL dan Berita Acara Pemeriksaan (BAP), serta (3) bukti dokumentasi foto. Meski sudah berjalan, namun capaian kinerja monev RKL-RPL dianggap masih belum optimal karena mengandung sejumlah kelemahan.

Berdasarkan persepsi para informan, terdapat setidaknya 12 kelemahan yang harus dibenahi dalam pelaksanaan monev RKL-RPL meliputi komitmen pemerintah daerah yang rendah, informasi lembaga publik yang minim, ketiadaan transparansi dan partisipasi publik dalam proses monev RKL-RPL. Kekurangan lainnya berupa penegakan hukum yang lemah, peningkatan kapasitas pemrakarsa dan pengawas yang minim, stigma negatif karena ulah oknum internal, anggaran monev yang terbatas, manajemen monev yang buruk dan sarana-prasarana pendukung monev yang tidak memadai. Kelemahan yang ada menyebabkan BLH tidak optimal dalam menjalankan monev RKL-RPL.

Dampak berikutnya menyebabkan ketaatan pemrakarsa menjadi berkurang sehingga dalam menjalankan kegiatan usaha tidak memperhatikan kelestarian lingkungan. Tidak berjalannya pengelolaan lingkungan menyebabkan buangan limbah/emisi yang dihasilkan tidak memenuhi baku mutu dan mencemari lingkungan. Dampak negatif pencemaran tidak hanya berdampak secara fisik (alam) namun telah memicu masalah sosial, menurunkan tingkat kesehatan dan menganggu roda perekonomian masyarakat. Berbagai persepsi informan beserta hasil observasi lapangan dan studi pustaka seputar capaian kinerja BLH dalam implementasi RKL-RPL penulis dijabarkan menjadi ke dalam tiga bagian yakni (1) deskripsi persepsi, (2) konseptualisasi persepsi (3) model hubungan antar konsep.

\section{Konseptualisasi Persepsi Publik terhadap Kinerja Monev RKL-RPL}

Sebanyak 12 (dua belas) tema diatas merupakan hasil sintensis antar unit-unit informasi yang didapatkan dari hasil wawancara mendalam, observasi lapangan dan studi pustaka serta dokumentasi selama penelitian. Menurut Karidewi (2010), sintesis merupakan upaya untuk mencari keterkaitan antara satu kategori atau unit informasi dengan kategori atau unit informasi lainnya yang kemudian dari kaitankaitan tersebut menghasilkan tema-tema. Selanjutnya tema-tema tersebut dikonseptualisasi dengan cara abstraksi untuk menghasilkan konsep-konsep tertentu.

Masih menurut Karidewi (2010), abstraksi merupakan usaha untuk membuat rangkuman yang inti. Sedangkan konsep adalah gambaran keterhubungan antar tema. Dalam tahapan ini, sangat mungkin terjadi satu tema mengarah pada satu atau lebih konsep yang ada. Sebaliknya, satu konsep dapat terdiri dari berbagai macam tema tergantung pada ada/tidaknya keterkaitan antara materi dalam tematema tersebut dengan konsep yang dimaksud. Konsepkonsep yang berhasil diperoleh terdiri atas enam topik meliputi mekanisme kontrol publik, integrasi fungsi monev RKL-RPL, penguatan basis legal, fleksibilitas anggaran, manajemen aparatur dan kemitraan kolaboratif. Dalam Gambar 1 tersaji hubungan yang terjalin antara konsep yang satu dengan yang lain.

\section{Hubungan Antar Konsep}

Enam konsep yang dihasilkan dari tema yang ada yakni mekanisme kontrol publik, integrasi fungsi monev RKL-RPL, manajemen aparatur, penguatan basis legal, fleksibilitas anggaran dan kemitraan kolaboratif memiliki hubungan yang saling mempengaruhi antara satu dengan yang lain. Hubungan yang terjalin antar konsep bersifat timbal balik dan saling mempengaruhi antara satu dengan yang lain. Dari enam konsep yang ada, peneliti berpendapat kemitraan kolaboratif merupakan topik 
utama yang melatarbelakangi kemunculan lima konsep lainnya meliputi mekanisme kontrol publik, penguatan basis legal, fleksibilitas anggaran, integrasi fungsi monev, dan manajemen aparatur. Model hubungan antara tiap-tiap konsep disajikan dalam Gambar 2.

Mekanisme kontrol publik merupakan pedoman yang mengatur bentuk-bentuk partisipasi publik dalam monev RKL-RPL. Perwujudan mekanisme kontrol publik akan mendorong pemberdayaan masyarakat sebagai kekuatan kontrol dalam monev RKL-RPL. Definisi publik yang dimaksudkan dalam pembahasan ini adalah berbagai kekuatan sipil yang ada di masyarakat meliputi LSM, ormas maupun masyarakat secara umum. Peranserta publik dalam monev RKLRPL publik akan mendorong terwujudnya kemitraan kolaboratif yakni suatu bentuk sinergi dan kerjasama tripartit antara pemerintah, pemrakarsa dan publik itu sendiri. Ketiga pihak yang terlibat dalam kemitraan kolaboratif diposisikan sebagai mitra/rekan kerja yang memiliki kedudukan setara, saling bekerjasama dan menghargai antara satu dengan yang lain. Kemitraan kolaboratif menolak adanya dominasi salah satu pihak terhadap pihak lain yang memiliki kepentingan berbeda. Kemitraan kolaboratif memberikan kesempatan dan hak serta kewajiban yang sama kepada setiap pihak untuk memberikan kontribusi sesuai kapasitas dalam bingkai aturan yang berlaku. Selama ini, monev RKL-RPL bersifat tertutup karena hanya didominasi oleh BLH sebagai pelaksana monev dan pemrakarsa sebagai pelaksana RKL-RPL. Padahal, tanpa adanya partisipasi publik, maka kemitraan kolaboratif yang transparan, adil dan objektif tidak akan pernah terwujud .

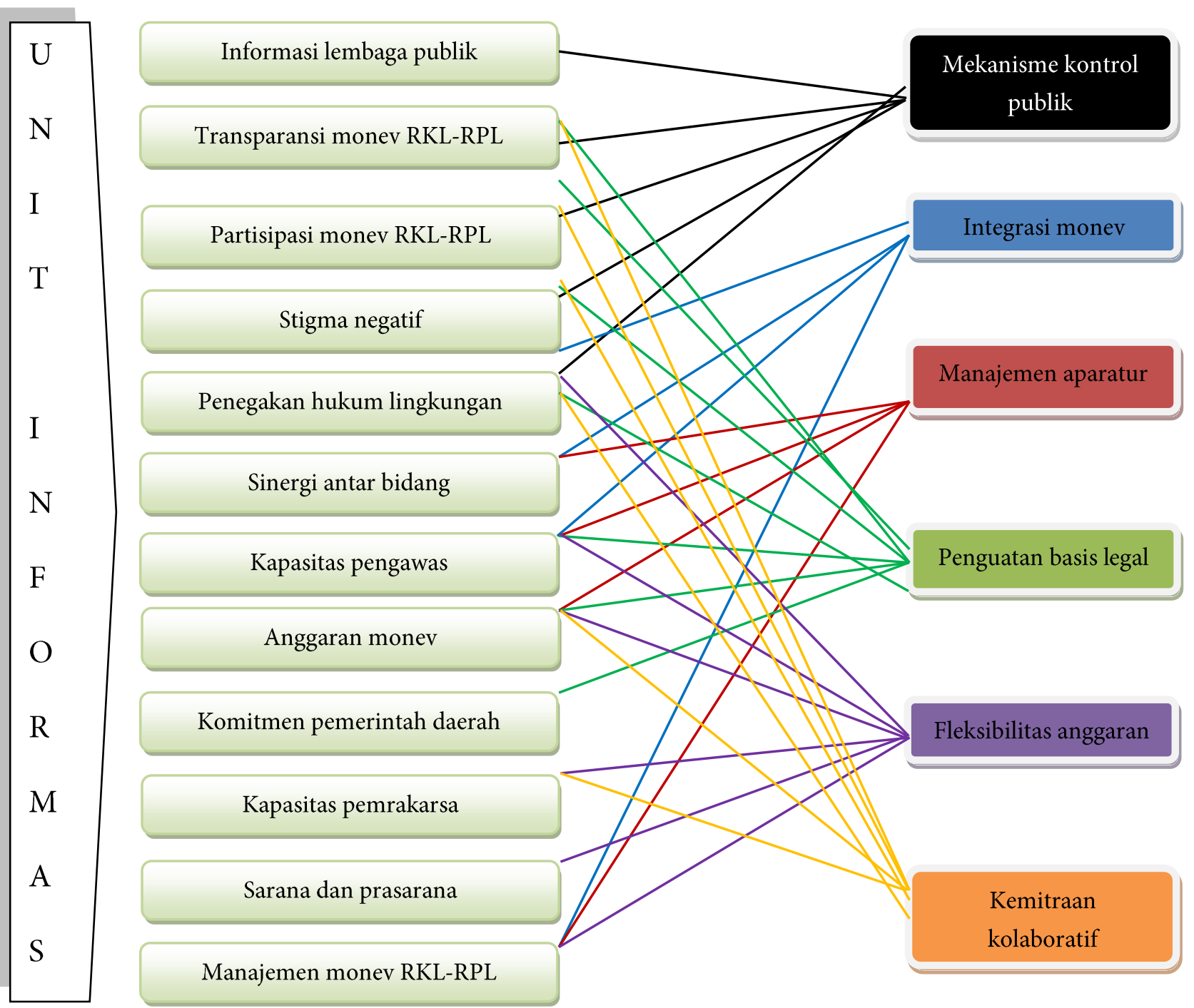

Gambar 1. Matrik Induksi Konsep

Sumber : Hasil Perumusan (2015) 


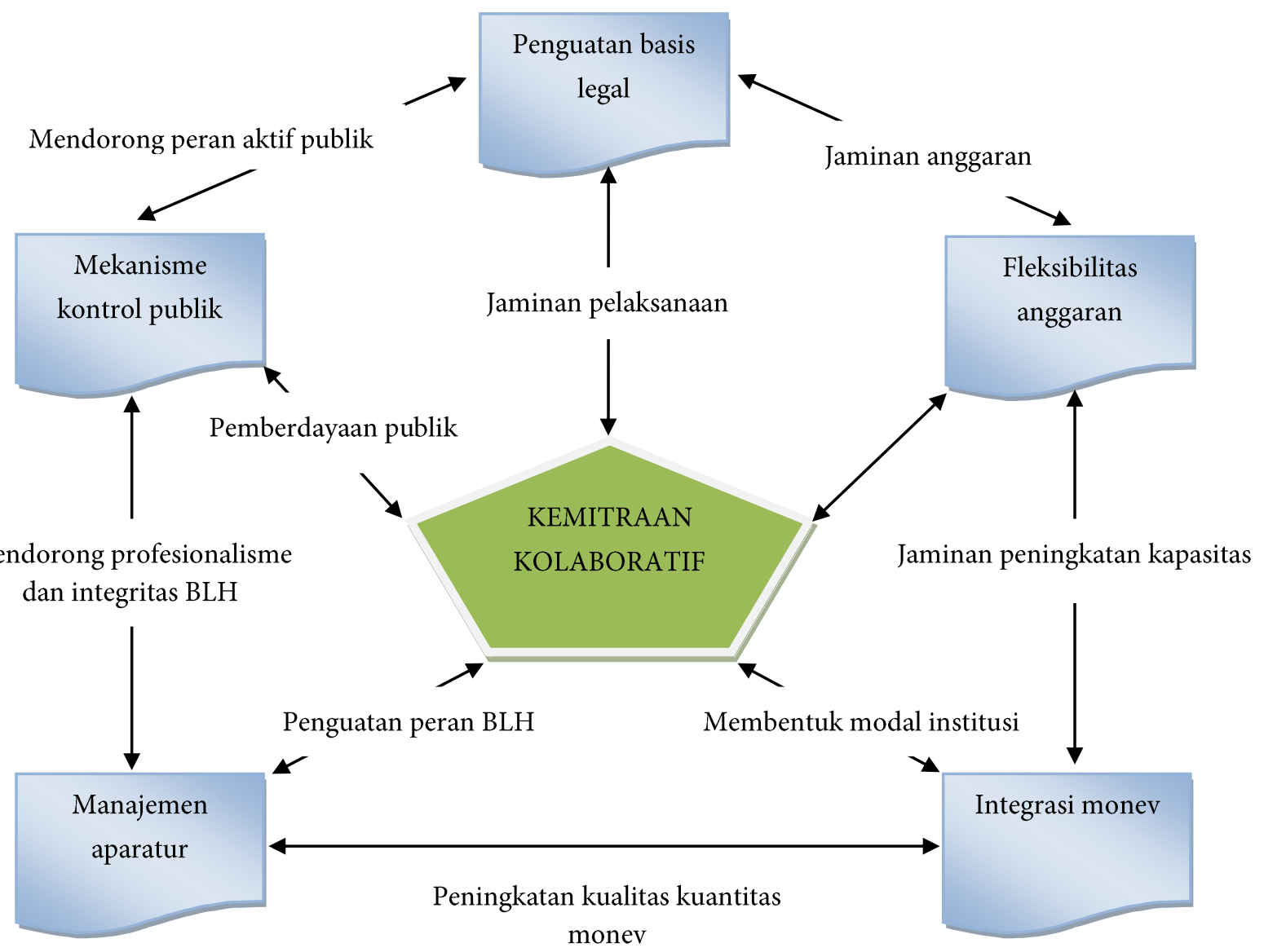

Gambar 2. Hubungan Interelasi Antar Konsep

Sumber : Hasil Perumusan (2015)

Selain sebagai sarana pemberdayaan publik, mekanisme kontrol publik akan memberi akses kepada masyarakat untuk dapat mengawasi kinerja BLH dalam monev RKL-RPL. Publik akan mampu memantau capaian kinerja dan berbagai penyimpangan yang mungkin muncul dalam monev RKL-RPL. Fungsi kontrol yang dilakukan publik secara otomatis akan mendorong BLH bekerja secara lebih serius dalam menjalankan tupoksi di bidang perlindungan lingkungan hidup. BLH menyadari kelalaian dalam menjalankan monev RKL-RPL maka akan menuai reaksi dan tekanan publik. Untuk itu, BLH akan senantiasa melakukan perbaikan internal agar mampu memberikan pelayanan prima yang sesuai harapan publik. Wujud konkretnya adalah dengan meningkatkan kapasitas personel, menanamkan integritas dan menegakkan disiplin atas setiap pelanggaran yang dilakukan oleh oknum BLH.

Namun, adanya mekanisme kontrol publik tidak secara otomatis akan mendorong kesadaran masyarakat untuk terlibat secara aktif dalam monev RKL-RPL. Penyebabnya karena belum adanya payung hukum yang secara spesifik mampu memberi perlindungan bagi pelaksanaan mekanisme kontrol publik itu sendiri. Ketiadaan aturan hukum ini memicu kekhawatiran terhadap munculnya praktik kriminalisasi oleh pihak - pihak yang merasa terganggu oleh akvitas kontrol publik. Terlebih lagi, komitmen pemerintah untuk melindungi hak-hak publik dalam berbagai kasus sengketa lingkungan sangat minim bahkan kerap berada pada kubu yang saling berseberangan. Atas dasar ini, diperlukan sebuah payung hukum dalam bentuk peraturan daerah (perda) yang akan memberikan jaminan dan perlindungan terhadap mekanisme kontrol publik.

Ketentuan yang diatur dalam perda ini melingkupi hak dan kewajiban serta sanksi terhadap segala bentuk pelanggaran terhadap kewajiban lingkungan. Payung hukum ini juga dimaksudkan sebagai upaya penguatan basis legal terhadap aturan perlindungan lingkungan 
hidup yang sudah ada. Dengan adanya perda ini diharapkan akan mampu memberikan perlindungan, keadilan dan kepastian hukum bagi semua pihak yang terlibat dalam monev RKL-RL. Sehingga, publik akan terdorong lebih aktif dalam melakukan aktivitas kontrol monev RKL-RPL tanpa merasa takut dikriminalisasi karena telah ada jaminan hukum dari pemerintah.

Adanya payung hukum dalam bentuk peraturan daerah merupakan jaminan bagi keberlangsungan kemitraan kolaboratif dalam monev RKL-RPL. Sebab, segala ketentuan yang digariskan dalam perda tersebut bersifat mengikat dan memaksa seluruh pihak tanpa kecuali. Dengan memiliki landasan hukum yang kuat, maka setiap bentuk kerjasama dan program kegiatan yang mendukung kemitraan kolaboratif dalam monev RKL-RPL akan senantiasa terakomodasi dan mendapat dukungan pemerintah daerah. Sehingga, apapun dinamika politik dan gejolak ekonomi yang terjadi di daerah tidak akan menghambat realisasi program kemitraan kolaboratif khususnya dalam monev RKLRPL.

Namun, tuntutan perwujudan kemitraan kolaboratif melalui berbagai sarana dan program kerja secara otomatis memerlukan alokasi dana bagi pembiayaan operasional kegiatan. Tanpa dukungan anggaran yang memadai, maka konsep sebagus apapun dalam mendukung kemitraan kolaboratif mustahil dapat terlaksana. Terlebih lagi bagi institusi BLH yang sumber pendanaan bersifat kaku dan terbatas pada APBD. Padahal, BLH memiliki peran penting sebagai pengawas dalam monev, pembina pemrakarsa dan fasilitator partisipasi publik dalam monev RKL-PRL melalui berbagai sarana dan program kegiatan. Selama ini, pengalokasian anggaran perlindungan lingkungan hidup sangat dipengaruhi oleh kebijakan pimpinan mulai dari Kepala BLH, Bupati hingga DRPD. Mekanisme semacam ini menjadikan usulan alokasi anggaran rawan diintervensi oleh berbagai kepentingan politik dan ekonomi oknum-oknum tertentu yang tidak sejalan dengan semangat perlindungan lingkungan hidup. Atas dasar ini, dipandang perlu memasukkan kewajiban alokasi anggaran minimal dalam APBD ke dalam perda perlindungan lingkungan hidup yang ada. Untuk memberi kemudahan dalam pemanfaatan alokasi dana yang ada, perlu ditambahkan pasal yang memberikan fleksibilitas/kelonggaran bagi BLH untuk menggunakan anggaran nonpengawasan bagi kegiatan monev RKL-RPL. Hal ini dimaksudkan sebagai solusi ketika anggaran monev RKL-RKL yang tersedia telah lebih dahulu habis sebelum tutup anggaran. Dengan adanya ketentuan ini akan memberikan jaminan ketersediaan anggaran yang memadai bagi pelaksanaan monev RKL-RPL. Dukungan anggaran yang memadai diharapkan akan mampu mewujudkan kontribusi dan peran serta BLH, publik dan pemrakarsa dalam kemitraan kolaboratif secara optimal dan terus menerus.

Bagi internal BLH, dukungan anggaran yang memadai akan mempermudah peningkatan kompetensi personel melalui pendidikan dan pelatihan (diklat) Pejabat Pengawas Lingkungan Hidup (PPLH). Keikutsertaan dalam diklat akan meningkatkan kompetensi personel dan kapasitas institusi dalam menjalankan fungsi monev RKL-RPL. Namun, pengiriman personel untuk mengikuti diklat PPLH bukan hanya untuk memenuhi kebutuhan tenaga profesional dalam bidang pengawasan lingkungan. Secara lebih jauh sebagai sarana untuk mewujudkan integrasi monev RKL-RPL dalam tubuh institusi BLH itu sendiri. Caranya adalah dengan mengirimkan para personel BLH dari dalam dan luar bidang Wasdal untuk mengikuti diklat PPLH. Pasca diklat diharapkan akan terbentuk kesadaran untuk saling bekerjasama dan membuang jauh ego sektoral yang selama ini menghambat konektivitas antarbidang. Perwujudan integrasi monev RKL-RPL dan budaya sinergi antar bidang menjadi modal beharga bagi BLH untuk dapat berperan secara optimal dalam kemitraan kolaboratif.

Namun, integrasi monev melalui diklat PPLH belumlah cukup karena sebatas mempersiapkan SDM yang memiliki kompetensi. Diperlukan suatu pola manajemen aparatur yang mampu mendayagunakan seluruh potensi SDM agar menghasilkan kinerja monev RKL-RPL secara optimal. Melalui peningkatan kompetensi yang dipadukan dengan manajemen aparatur yang baik akan mampu menghasilkan peningkatan kualitas dan kuantitas monev RKL-RPL. Dari sisi kualitas, monev RKL-RPL mampu menghasilkan kinerja pengawasan yang memenuhi standar minimal yang berlaku. Adapun dari sisi kuantitas, monev RKL-RPL mampu melingkupi seluruh objek pengawasan.

Optimalisasi seluruh sumber dayai institusi akan mampu memperkuat peran BLH kemitraan kolaboratif. Ketika peran BLH sebagai pelaksana monev, pembina pemrakarsa dan fasilitator publik berjalan dengan baik, maka akan turut mendorong peran aktif pemrakarsa dan publik dalam memperkuat monev RKL-RPL. Ketika pemrakarsa, publik dan BLH dapat berperan secara optimal, maka kualitas sinergi dan kerjasama yang terjalin dalam kemitraan 
kolaboratif akan semakin baik pula. Namun, ketika BLH tidak melakukan pembinaan dan peningkatan kapasitas pemrakarsa, tidak melakukan pubilkasi dan partisipasi publik dalam monev RKL-RPL, maka peran pemrakarsa dan publik menjadi tidak optimal. Kondisi ini akan menimbulkan dominasi salah satu pihak yakni BLH terhadap pihak lain yakni pemrakarsa dan publik. Kondisi timpang semacam ini jelas bertentangan dengan konsepsi kemitraan kolaboratif yang berasaskan kesetaraan, penghargaan dan sikap saling membutuhkan antara satu dengan yang lain.

\section{Faktor-Faktor yang Mempengaruhi Kinerja Monev RKL-RPL}

Kinerja BLH dalam monev RKL-RPL sangat dipengaruhi oleh sejumlah faktor baik yang bersifat internal maupun eksternal. Faktor internal merupakan faktor-faktor yang muncul dari internal organisasi BLH Kobar. Sedangkan faktor eksternal dipicu oleh pihakpihak dari luar organisasi BLH. Faktor-faktor internal dan eksternal diperoleh dari persepsi, penilaian dan tanggapan informan selama proses wawancara mendalam. Faktor-faktor tersebut ada yang memberi dampak positif dan ada pula yang berdampak negatif bagi kinerja BLH dalam monev RKL-RPL. Namun, dalam pemaparan kali ini peneliti hanya akan memfokuskan pembahasan pada faktor-faktor internal dan eksternal yang menghambat kinerja monev RKLRPL. Faktor internal yang menghambat kinerja BLH antara lain kepentingan politis kepala daerah, patologi (penyakit) birokrasi, dan alasan kemanusiaan. Sedangkan faktor eksternal yang mempengaruhi kinerja BLH terbagi menjadi tiga yakni kendala teknis, kebijakan manajemen, dan ketiadaan pengumpul Limbah Bahan Berbahaya dan Beracun (LB-3) berizin.

\section{Strategi Monev RKL-RPL}

Kinerja monev BLH hingga kini belum memenuhi harapan publik. Masih ditemukan banyak kelemahan dan hambatan baik bersifat internal maupun eksternal dalam pelaksanaan monev RKL-RPL. Untuk itu, diperlukan adanya rumusan strategi sebagai solusi konkret yang efektif dalam menyelesaikan berbagai persoalan dan mampu meningkatkan kinerja monev RKL-RPL daripada periode sebelumnya. Rumusan strategi diperoleh dari hasil wawancara dan diskusi dengan berbagai responden yang terlibat dalam proses monev RKL-RPL. Strategi yang dijalankan menempatkan BLH sebagai aktor utama dengan tetap mengakomodasi aspirasi dan ruang partisipasi berbagai komponen diluar pemerintah. Strategi yang dapat dijalankan BLH untuk meningkatkan kinerja monev
RKL-RPL ada delapan langkah antara lain (1) revisi program prioritas pemerintah daerah, (2) penyusunan perda pendukung monev, (3) pengembangan program publikasi monev, (4) memfasilitasi pembentukan forum diskusi dan komunitas sosial peduli lingkungan, (5) perbaikan manajemen SDM, (6) peningkatan kapasitas pemrakarsa secara berkala, (7) peningkatan sarana dan prasarana pendukung monev, dan (8) revisi teknis pelaksanaan monev RKL-RPL.

\section{KESIMPULAN}

1. Secara umum kinerja BLH dalam monev RKL-RPL sudah berjalan namun belum optimal karena masih mengandung sejumlah kelemahan. Kinerja monev RKL-RPL dinilai sudah berjalan berdasarkan atas tiga indikator yakni (1) pengakuan dari para informan, (2) dokumen administrasi berupa laporan RKL-RPL dan Berita Acara Pemeriksaan (BAP), serta (3) bukti dokumentasi foto. Meski sudah berjalan, namun capaian kinerja monev RKL-RPL masih belum optimal karena terdapat setidaknya 12 kelemahan yang harus dibenahi dalam pelaksanaan monev RKL-RPL meliputi komitmen pemerintah daerah yang rendah, informasi lembaga publik yang minim, ketiadaan transparansi dan partisipasi publik dalam proses monev RKL-RPL. Selain itu, penegakan hukum yang lemah, peningkatan kapasitas pemrakarsa dan pengawas yang minim, muncul stigma negatif karena ulah oknum internal, anggaran monev yang terbatas, manajemen monev yang buruk dan sarana-prasarana pendukung monev yang tidak memadai. Konsepsi persepsi responden terhadap kinerja BLH dalam monev RKL-RPL yang berhasil diperoleh sebanyak 6 (enam) konsep antara lain mekanisme kontrol publik, integrasi fungsi monev RKL-RPL, penguatan basis legal, fleksibilitas anggaran, manajemen aparatur dan kemitraan kolaboratif. Keenam konsep ini memiliki hubungan yang bersifat timbal balik dan kemitraan kolaboratif merupakan konsep utama yang melatarbelakangi lima konsep lainnya.

2. Faktor-faktor yang mempengaruhi kinerja BLH dalam monev RKL-RPL terdiri atas faktor internal dan faktor eksternal. Faktor-faktor internal meliputi kepentingan politis kepala daerah, patologi birokrasi, dan faktor kemanusiaan. Adapun faktorfaktor eksternal yang mempengaruhi kinerja $\mathrm{BLH}$ adalah kendala teknis, manajemen perusahaan dan ketiadaan pengumpul limbah bahan berbahaya dan beracun (LB-3) berizin. 
3. Strategi yang dapat dijalankan BLH untuk meningkatkan kinerja BLH dalam monev RKL-RPL ada 8 (delapan) langkah antara lain dengan merevisi program prioritas pemerintah daerah, penyusunan perda pendukung monev RKL-RPL, pengembangan program publikasi lingkungan berbasis internet, memfasilitasi pembentukan forum diskusi dan komunitas sipil peduli lingkungan, perbaikan manajemen SDM, melakukan peningkatan kapasitas pemrakarsa secara berkala, peningkatan sarana dan prasarana pendukung monev RKL-RPL dan revisi teknis pelaksanaan monev RKL-RPL.

\section{DAFTAR PUSTAKA}

BLH Kobar. (2014). Status Lingkungan Hidup Daerah (SLHD) Kobar Tahun 2014. BLH Kabupaten Kobar.

BPS Kobar. (2014). Kotawaringin Barat Dalam Angka (KDA) Tahun 2014. BPS Kabupaten Kobar.

Dwiyanto, Agus. (2006). Reformasi Birokrasi Publik Di Indonesia. Yogyakarta: Gadjah Mada University Press.

Dwiyanto, Agus. (2002). Membangun Sistem Pelayanan Publik yang Memihak pada Rakyat. Jurnal Populasi. 13 (1).

Dwiyanto, Agus. (1995). Penilaian Kinerja Organisasi Pelayanan Publik, Makalah Seminar Kinerja Organsasi Publik Kebijakan dan Penerapannya. Yogyakarta : Jurusan Ilmu Administrasi Negara Fisipol UGM.

Etzioni, Amitai. (1976). Modern Organizations. India : Prentice-Hall, inc.

Goggin, Malcolm L. (1990). Implementation Theory and Practice : Tward a third generation. USA : Foresman and Company.
Karidewi, Made Putri. (2010). Kajian Eksistensi Kearifan Lokal Masyarakat Desa Adat Tenganan Pegringsingan Dalam Pengelolaan Hutan Di Desa Tenganan, Kecamatan Manggis, Kabupaten Karangasem, Provinsi Bali. Tesis. Yogyakarta : Sekolah Pascasarjana. Universitas Gadjah Mada.

Lenvine, Charles H. (1990). Public Administration : Chalengges, Choices, Conseques. England : Scott Foresman/Little Brown Higher Education, Illinois.

Moleong, Lexy J. (2001). Metode Penelitian Kualitatif. Bandung : Remaja Rosdakarya.

Hasibuan, Malayu SP. (1996). Organisasi dan Motivasi, Dasar Peningkatan Produktivitas. Jakarta : Bumi Aksara.

Hasibuan, Malayu SP. (1985). Manajemen : Dasar, Pengertian dan Masalah. Jakarta: Gunung Agung.

Salusu, J. (1996). Pengambilan Keputusan Stratejik Untuk Organisasi Publik Nonprofit. Jakarta : Gramedia.

Straus, Anselm dan Juliet Corbin. (alih bahasa oleh Muhammad Shodiq dan Immam muttaqien). (2009). Dasar-Dasar Penelitian Kualitatif. Yogyakarta : Pustaka Pelajar.

Subarsono, AG. (2005). Analisis Kebijakan Publik : Konsep, Teori dan Aplikasi. Yogyakarta : Pustaka Pelajar.

Sutrisno, Edy. (2011). Manajemen Sumber Daya Manusia. Jakarta : Kencana Media Group.

Tohardi, Ahmad. (2002). Pemahaman Praktis Manajemen Sumber Daya Manusia. Bandung : Mandar Maju.

Thoha, Miftah. (2007). Perilaku Organisasi : Konsep Dasar dan Aplikasinya. Jakarta : Raja Grafindo Persada.

Widodo, Joko. (2001). Good Governance. Surabaya : Insan Cendekia. 